\title{
PLANT SELECTION CRITERIA FOR LANDSCAPING IN GULBARGA
}

\author{
Paranjyoti R.Patil \\ Department of Architecture, Poojya Doddappa Appa College of Engg, Gulbarga, Karnataka, INDIA: \\ paranjyotirpatil@gmail.com
}

\begin{abstract}
Plants are part and parcel of any urban landscape. Plants in urban areas serve many functions. They are preferred for climatic, environmental, visual, medicinal, functional and religious purposes. Planting design being a part of process of landscaping, it needs to be based on site conditions. Gulbarga poses limiting conditions for growth of plants in terms of hot dry climate, soil type and water quality and physical environment. Plant selection becomes a major task in landscape process. Analyses of effects of these limiting conditions on plants are necessary to make planting successful. Plant selection criteria are worked out based on the limiting factors and adaptability of the plants to make landscaping successful.
\end{abstract}

Keywords: plants in urban environment, planting design, hot dry climate, black soil, hard water, plant selection, criteria of plant selection

\section{INTRODUCTION}

Plants are integral part of urbanscape. With their presence they define the spaces which lie between the buildings, roads, open spaces and water bodies. Not only they provide visual pleasure, but they integrate natural landscape with that of man made. Presence of plants has brought many fold benefits to human being. These may be in the form of visual pleasure, food chain, main contributor to environment or asserting certain functions as desired by the human being. Our ancestors knew the very important role of plants for the survival of living beings. The ecosystem was well realized and was given due importance. They are regarded as sacred in various religions.

\subsection{Role of Plants in Urban Environment:}

Plants are used for many purposes in urban areas. These may be for functional, environmental, visual, medicinal or for religious purposes. As an element to define certain functions, plants are used for space division, alignment, for unifying larger areas, for shade or in the form of architectural rooms. Plants contribute in modifying urban environment as they absorb carbon dioxide; act as sound barrier and help in dust reduction or for micro climate modulation. They are used for water retention, fertility improvement, Slope stabilization and for retarding soil erosion. With their colour, texture and mass, they create visual pleasure. They are used for emphasizing undulation, creation of vistas, formation of visual axis, screening unwanted views and for curve reinforcement. They form beautiful back drops or fore grounds for the appreciation of buildings and they help in enframing the views.

\section{PLANTING DESIGN}

As one goes ahead with landscaping for a given area, plant selection and designing with plants is one of the crucial stages in landscape planning. This requires sufficient details about the plants and their growth habits. Planting design not only deals with visual aspects of planning but also with soils, climate, water and as well as effects of surrounding physical environment. The plant selection needs to be based on consideration of above factors in detail to make planting successful.

As climate, soil and water are the major deciding factors for the success of any type of vegetation, it is highly necessary to know about the effect of these factors on plant material in given condition of urban area. Many problems crop up while selecting plant materials in a place like Gulbarga which experiences hot dry climate, alkaline water and black soil. Analysis of these limiting conditions and growth of vegetation in such condition need to be understood for plant selection for given purpose.

\subsection{Planting in Gulbarga:}

The city is located in the northern plains of Karnataka in India.

Physiography: This area falls under northern dry maidan Region.

Climate: Gulbarga experiences hot dry climate. April and may being the hottest period in summer and coldest month being December. Peak summer temperature rises to $45^{\circ} \mathrm{C}$. Mean monthly temperature ranges from 22 to $25^{\circ} \mathrm{C}$ in the month of January and 33-38degree centigrade in May and June. Relative humidity is $26 \%$ in summer and $62 \%$ in winter. 
Rain fall is $630 \mathrm{~mm}$ to $800 \mathrm{~mm}$ and normal rainy days are 46 . South west monsoon sets in the second week of June and ends by September. $75 \%$ of rain fall is during this period.

Soil: majority of the area is covered by deep black soil and medium black soil and shallow soil. Black soil is derived from basaltic rocks. Infiltration rate is moderate to poor $(2.5 \mathrm{~cm} / \mathrm{hr})$. Gulbarga comprises sedimentary formation viz, sand stone, quartzite, shale, slate, lime stone and dolomite. Deccan trap basalt covers larger area. The soil is slightly alkaline in reaction and calcareous in nature. Texture is loam to clay and is highly retentive in nature. And have high base saturation. The soil shrinks and opens with cracks in summer and swells and closes during rainy season. These are fertile and productive when moisture is not a limiting factor. They are low in organic matter and high in plasticity and stickiness. They commonly show excess accumulation of soluble salts in the surface horizon.

Vegetation: Type of vegetation is mainly the grasses, thorny xerophytic shrubs, and trees like Acacia sp., Azadirchta indica , Ficus benghalensis, Thivetia peruviana, Tamarindus indica etc.

Water: Majority of the city has hard water. Only a part of east enjoys soft water. Hardness of water varies from 500 to 1150 $\mathrm{mg} / \mathrm{ltr}$. Values of $\mathrm{pH}$ varies from 6.8 to 7.98 , Chloride content varies from 200 to $400 \mathrm{mg} / \mathrm{ltr}$. Alkalinity of the water is from 200 to $300 \mathrm{mg} / \mathrm{ltr}$.

Physical Environment: vernacular settings within the city (old city) show a closely knit urban fabric which is due to hot dry climatic conditions. Mutual shading of buildings provides relief to greater extent from heat penetration through sun radiation. Extension areas having smaller plots show similar condition where as large plot areas show sufficient open spaces in between the buildings and thus larger part of the building exposed to sun. Such conditions are highly uncomfortable during summer If not sheltered by trees or neighboring tall buildings.

\subsection{Effects of Climate, Soil, Water and Physical}

\section{Environment on Plants:}

Semi arid climate has been causing many difficulties in growth of plants. In addition to that, the black soil and the alkaline water also add to the difficulty. Christopher Driver writes that the difficulty arises as high evapotranspiration rates ensure that the potential for water loss exceeds the quantity of water available for use. Second difficulty arises when certain chemical processes in plants are sufficiently intensified to cause plant death in non adapted species. High radiation levels also lead to higher soil temperature which has significant effect on plant growth rates. [x]
The temperature variation within a year varies from $45^{\circ} \mathrm{C}$ to as low as $15^{\circ} \mathrm{C}$ and $10^{\circ} \mathrm{C}$. This large variation causes difficulty for plants to adapt to the climate when they are young and also for the moderately grown plants which are not indigenous. This either results into stunted growth or death of plants.

Hot and dry winds are regular features in summer. They increase evapotranspiration rates and thereby adding to the problem in growth.

- High radiation levels are responsible for the accumulation of the soluble products of weathering that is calcium carbonate and soluble mineral salts in upper part of soil profile.

- Areas having deep black soil when experience heavy rain fall, are waterlogged due to the presence of high clay content and low infiltration rate and hydraulic conductivity. In such cases plants adapted to semi arid climate suffer.

- Shrinkage and swelling of black soil in summer and winter also cause breakage of young roots. This is found to be fatal for lawns and young plants.

- Leaves of wide leaved plants get burnt due to high radiation in summer causing an unpleasant look and also slow growth.

- Wide roads and large junctions of roads cause heat islands in the city. Hence planting along the roads and within the circles in summer have proved to be challenging in the process of plant selection as the death rate is high in the initial stages of development of plant.

\subsection{Criteria for Selection of Plants for Gulbarga:}

To make planting successful in the climatic condition of Gulbarga, above discussed factors need to be taken into account before heading for selection. Apart from this, the selection of tree species should reflect the designers understanding of the purpose of the site and its architectural character, the tree being of the appropriate scale, shape, texture and color [2]. Functional, environmental and visual needs are to be addressed in the process of selection.

- Indigenous varieties have proven to be successful as they thrive well in the given condition. These are evolved over centuries in nature. They are the resultant of all natural forces, adaptations and survival ${ }^{[3] .}$ These also help to give distinct identity of the place.

- Localized varieties may be selected with due consideration of the site condition and particular place of planting and growth of surrounding plants in due course of time.

- $\quad$ Plants need to be selected from the nurseries located in places having similar climatic conditions or they need to be allowed to get acclimatized for a year.

- Small leaved plants thrive well as compared to large leaved ones. Due to mutual shading and less surface 
area exposure to sun makes them to survive in such situation.

- $\quad$ Plants with white sap are much disliked by animals. Hence they are more suitable for hedges and border plantation. They are also found to be reasonably resistant to high temperature and drought.

- Succulents and cactus varieties do well in Gulbarga due to the very nature of being xerophytes.

\subsection{Suitable Varieties}

Following are some of the suitable varieties which are found to be successful even in adverse conditions

Trees: Azardirachta indica, Ficus bengalensis, Parkinsonia aculeata, Eugenia jambolana, Mangifera indica, Ailanthus excelsa, Acacia decurrens, Bauhinia spp., Delbrgia sissoo, Ficus religiosa, Muntingia calaburra, Millingtonia hortensis, Nyctanthus arbortristis, Peltoforum pterocarpum, Plumeria varieties, Polyalthia longifolia, Prosipis juliflora, Santalum album, Terminalia catappa, Thivetia peruviana,

Shrubs: Nerium oleander, Tabernaemontana coronaria, Altrnenthera betzickiana, Berlaria cristata, Caesalpinia pulcherrima, Cestrum diurnum, Cestrum nocturnum, Clerodendrum inerme, Codiaeum spp., Crossandra undulaefolia, Duranta varieties, Hibiscus varieties, Ixora , Jasminum , Lantan spp.,Vinca rosea, Wadelia trilobata, Tecoma stans, Datura spp.

Climbers: Allamanda cathertica, Bougenvillea varieties, Clitoria ternatea, Ipomoea verieties, Jasmanium varities, Quamoclit pinnata, Quisquails indica.

\section{CONCLUSIONS}

Plants are vital elements in urban scenario. They are used for ecological, aesthetic, functional, religious and medicinal purposes. Planting design in landscaping is a major stage wherein plant selection becomes crucial. The selection of plants needs to be based on the physical environment, soil type, water quality and climate. Analysis of these factors with respect to plant needs to be done to make appropriate selection. Proper selection with respect to site conditions leads to successful landscaping. Observation of local varieties gives important clues for selection. Use of local varieties leads to successful landscaping and also gives distinct identity of the place.

\section{REFERENCES}

[1]. C.Driver," Planting in Hot Arid Climates", Brain Clouston, "Landscape design with plants", Heinemann Newnes, Oxford, 1990

[2]. Gordon Patterson, "Trees in Urban Area", Brain Clouston, "Landscape design with plants", Heinemann Newnes, Oxford, 1990
[3]. John Ormsbee Simonds, "Landscape Architecture - A Manual for Site planning and Design”, Mc Graw-Hill Book Company, New York. 